\title{
Toll-like receptor 4 as a predictor of clinical outcomes of estrogen receptor-negative breast cancer in Saudi women
}

\author{
Abdelhabib Semlali' \\ Maroua Jalouli² \\ Narasimha Reddy Parine' \\ Abdullah Al Amri' \\ Maha Arafah ${ }^{3}$ \\ Abdulrahman Al Naeem ${ }^{4}$ \\ Sanaa Abdullah Ajaj ${ }^{5}$ \\ Mahmoud Rouabhia ${ }^{6}$ \\ Mohammad Saud Alanazi' \\ 'Genome Research Chair, Department \\ of Biochemistry, College of Science, \\ King Saud University, Riyadh, Kingdom \\ of Saudi Arabia; ${ }^{2}$ Centre de recherche \\ du CHU de Québec, L'Hôtel-Dieu de \\ Québec, Department of Molecular \\ Biology, Medical Biochemistry and \\ Pathology, Université Laval, Quebec, \\ QC, Canada; ${ }^{3}$ College of Medicine, \\ King Saud University, ${ }^{4}$ Department \\ of Women's Imaging, King Fahad \\ Medical City, ${ }^{5}$ Department of Family \\ Medicine, College of Medicine, King \\ Saud University, Riyadh, Saudi Arabia; \\ ${ }^{6}$ Groupe de Recherche en Écologie \\ Buccale, Department of Stomatology, \\ Faculty of Dentistry, Université Laval, \\ Quebec, QC, Canada
}

This article was published in the following Dove Press journal:

OncoTargets and Therapy

24 February 2017

Number of times this article has been viewed

\begin{abstract}
The aim of this study was to investigate the association of the common polymorphisms of Toll-like receptor 4 (TLR-4) with breast cancer development in the Saudi Arabian population. Four TLR-4 polymorphisms (rs2770150, rs10759931, rs10759932, and rs4986790) were studied using 127 breast cancer patients and 117 controls. Relative expression of TLR-4 protein in the breast tumor and the matched normal breast tissues was determined in a large cohort of 70 clinical breast samples in a tissue micro-array format by immunohistochemistry using a specific anti-TLR-4 antibody. Our results demonstrated an increase in TLR-4 expression in estrogen receptor (ER)-, postmenopausal breast cancer patients compared to normal. We also demonstrated that the $\mathrm{G}$ allele of single-nucleotide polymorphism $r s 10759931$ was found to be significantly higher in frequency among patients (36.3\%) compared to the control group (26.7\%), suggesting that this polymorphism is strongly associated with the development of breast cancer in this ethnic population. In addition, the TLR-4 polymorphism rs 2770150 was shown to be highly correlated with breast cancer in patients over 48 years of age. The TLR-4 polymorphism rs4986790 was also found to be associated with this malignancy in the ER-patient groups. Our results suggested firstly that the variation in TLR-4 gene expression may influence breast cancer development and secondly a closely linked association between TLR-4 gene polymorphism and ER status. Our study provides support for a better understanding of the implication of TLR-4 polymorphism in breast tumorigenesis and for its eventual use as a cancer biomarker.
\end{abstract}

Keywords: Toll-like receptor 4, single-nucleotide polymorphisms, breast cancer, Saudi population, innate immunity, estrogen receptor

\section{Introduction}

Breast cancer is one of the most common cancers that threaten women's lives around the world, with approximately a $3 \%$ chance that a woman will die of breast cancer. ${ }^{1}$ Dynamic interplay between tumors and the immune system is essential for tumor survival, growth, and metastasis. ${ }^{2}$ Development of an invasive cancer is the result of genetic and epigenetic changes within the host. Studies provide clear evidence that genetic variants could be implicated in increasing breast cancer risk. ${ }^{3,4}$ The immune system is known to play a major role in preventing tumor progression by recognizing tumor antigens, and dysregulation of immune system activity could contribute to tumorigenesis. ${ }^{5}$ A dynamic association between immune response and breast cancer is important for its progression and incidence. ${ }^{6-8}$ Recent studies have shown that dysregulation of innate immunity receptors such as Toll-like receptors (TLRs) can promote cancer progression. ${ }^{9-12}$ To date, ten functional TLRs have been identified in humans as playing an active role in innate immunity through inflammatory cytokines 
such as interleukin (IL)-1 and IL-8. TLRs are also expressed in many cancer cells and are known to play a major role in tumor progression through regulating cell proliferation and survival. ${ }^{13,14}$ Of this TLR family, TLR-4 is a major TLR that plays an important role in regulating inflammation and immune responses through activating nuclear factor kappa-light-chain enhancer of activated B cells. ${ }^{15}$ This Toll protein is a key receptor for lipopolysaccharide (LPS) from Gram-negative bacteria and is crucial for upregulation of mechanisms of defense against bacterial infections. Several other pathogen-associated molecular patterns, including fusion protein from respiratory syncytial virus and envelope protein from mouse mammary tumor virus, can also stimulate TLR-4 signaling. ${ }^{16,17}$ In addition to activating the MyD88-dependent pathway, TLR-4 is the only TLR that can activate the MyD88-independent pathway via its TLR domain-containing adaptor. ${ }^{18}$ TLR-4 has received special attention in cancer research due to its role in tumor progression. It has been previously shown that TLR-4 is expressed in many cancer cells such as human melanoma cells, ${ }^{19}$ human gastric cancer cells, ${ }^{20}$ and human head and neck squamous cell carcinoma. ${ }^{21}$ In addition, TLR-4 has also been linked to breast cancer. Previous studies have demonstrated that TLR-4 depletion leads to increased tumor progression and metastasis in a murine model of breast cancer. ${ }^{9}$ There is evidence that genetic single-nucleotide polymorphisms (SNPs) may cause the impairment of immune responses, and consequently, the development of infectious diseases. The association between the development of infections and chronic inflammation could increase cancer risk. Few associations were observed between TLR genes and risk of developing breast cancer. Several studies highlighted the implication of TLR polymorphisms in pathogenesis of tumors. It was demonstrated that polymorphisms in TLR-2 and TLR-4 were associated with gastric cancer. ${ }^{22,23}$ Increasing bodies of evidence have suggested that TLR polymorphism is closely related to inflammation and may increase the risk of developing gastric malignancy. ${ }^{22,24,25}$ TLR-4 polymorphism was also connected with colon cancer ${ }^{26}$ and hepatitis $\mathrm{C}$ virus-induced hepatocellular carcinoma. ${ }^{27}$ In addition, a polymorphism in TLR-10, TLR-6, TLR-2, and TLR-1 was shown to be associated with increasing susceptibility of prostate cancer. ${ }^{28,29}$ Other studies have also presented the correlation between TLR-2 polymorphism and papillary thyroid cancer in the Korean population. ${ }^{30}$ Recently, several studies have demonstrated that the presence of the TLR-4 Asp299Gly polymorphism is associated with a higher frequency of prostate cancer in the North Indian population. ${ }^{31}$ It has also been shown that TLRs are implicated in the progression of polyps to tumors and that increased metastatic potential of colorectal cancers was correlated with reduced TLR expression. ${ }^{31,32}$ TLR-4 polymorphism rs11536898 has also been shown to be connected with colon cancer. ${ }^{26}$ The TLR-4 Asp299Gly polymorphism and TLR-2 Thr399Ile polymorphism were also observed to be associated with an increased risk of breast cancer. ${ }^{33,34}$ In addition, TLR-1 and TLR-6 polymorphisms have been linked with increased susceptibility of breast cancer in the African-American population. ${ }^{35,36}$ The present study aims to elucidate the potential correlation of the TLR-4 SNP (rs2770150, rs10759931, rs10759932, and rs4986790) with the risk of breast cancer in the Saudi Arabian population.

\section{Materials and methods Sample collection}

Blood samples were collected from 127 subjects with histologically confirmed breast cancer, recruited among patients from King Faisal Medical City (KFMC) in Riyadh, Kingdom of Saudi Arabia (KSA). A detailed description of the breast cancer population is shown in Table 1. All subjects provided written informed consent to participate in the study and to approve the use of their biological samples for genetic analyses. The design of the study was approved by the local Ethics Committee (number 15-089E) from KFMC, Riyadh. Study subjects provided information on their lifestyle habits, diabetes, and family/personal history of cancer via a structured questionnaire in accordance with the guidelines of the Ethics Committee at KFMC in Riyadh, KSA, to determine demographic characteristics and potential risk factors for breast cancer development. The immunohistochemical (IHC) assay was performed on the fresh tissue samples. The genomic DNA was extracted from blood samples for genotyping.

\section{IHC array}

IHC was performed on 3- to 5-mm thick sections obtained from formalin-fixed tissue embedded in paraffin. Histopathological

Table I Clinical characteristics of study subjects

\begin{tabular}{llll}
\hline Variable & Characteristic & Patients & Controls \\
\hline Total & - & 127 & 116 \\
Age (years) & $<48$ & 45 & 62 \\
(median age, 48 \pm 8.2$)$ & $>48^{*}$ & 82 & 54 \\
ER status & ER+ & 76 & - \\
& ER- & 49 & - \\
PR status & PR+ & 71 & - \\
& PR- & 55 & - \\
HER status & HER+ & 49 & - \\
& HER- & 78 & - \\
\hline
\end{tabular}

Note: $* \chi^{2}$ analysis showed significant difference between cases and controls. Abbreviations: ER, estrogen receptor; PR, progesterone receptor; HER, human epidermal growth factor receptor. 
representative tumor areas were defined on hematoxylin/ eosin-stained sections. The array blocks were obtained as described elsewhere. ${ }^{37}$ About $5-\mu \mathrm{m}$ sections from each tumor tissue block were consecutively cut with a microtome (Leica Microsystems GmbH, Wetzlar, Germany). Once the slides were ready, they were incubated for 15-20 minutes in a hot air oven at $60^{\circ} \mathrm{C}$. Anti-TLR-4 antibody (H-80, sc-10741; Santa Cruz Biotechnology, CA, USA) was used at 1/100 dilution. Different steps and analyses of IHC were then performed as previously described by Semlali et al. ${ }^{38}$

\section{DNA extraction}

Three hundred microliters of whole blood was used to extract genomic DNA by using DNA Blood Mini Kit (Qiagen, Qilden, Germany) according to the manufacturer's instructions. After equilibration of blood at room temperature with protease, the blood samples were incubated at $56^{\circ} \mathrm{C}$ for 10 minutes. Appropriate volume of absolute ethanol was added, and the mixture was spun through the column. The column membrane was washed, and the DNA was eluted with $100 \mu \mathrm{L}$ elution buffer. The concentration and the purity of DNA were determined by NanoDrop 800 spectrophotometer (Thermo Fisher Scientific).

\section{Genotyping}

TLR-4 SNPs (rs2770150, rs10759931, rs10759932, and rs4986790) were assessed using TaqMan assay as previously described. ${ }^{39}$ The positional information of the SNPs is described in Table S1. For this purpose, about $10 \mathrm{ng}$ of DNA from each sample was used per reaction with $5.6 \mu \mathrm{L}$ of $2 \mathrm{X}$ Universal Master Mix and $200 \mathrm{nM}$ primers. All genotypes were determined by using an ABI 7500 real-time PCR machine.

\section{Statistical analysis}

As described previously by Semlali et al, ${ }^{38}$ genotype and allelic frequencies were compared using Fisher's exact test (twotailed) to calculate the $\chi^{2}$ value with Yates corrections, and allelic odds ratios (ORs) with 95\% confidence intervals (CIs). Statistical analysis was performed using SPSS (Statistical Package for the Social Sciences) 16.0 software for Windows.

\section{Results}

\section{Analysis of clinical data parameters}

A total of 127 breast cancer cases and 117 healthy controls were enrolled in the study. The clinical characteristics of the patients, including age, nationality, estrogen receptor (ER) status, family history, and stage of breast cancer, were recorded and compared to the control patients. The study population was divided into two age groups: under 48 years and over 48 years (Table 1).

\section{Evaluation of expression of TLR-4 protein in breast cancer tissues}

TLR-4 has been reported as an indicator of various types of cancers. In the present study, we investigated whether the expression of TLR-4 in breast cancer has any prognostic value in the Saudi population and whether TLR-4 expression is related to the TLR-4 polymorphism specially located in the regulatory regions (promoter and $5^{\prime}$ upstream). The expression of TLR-4 protein in breast cancer and normal tissues was determined in a large cohort of 70 clinical breast samples in a tissue micro-array format by IHC. As shown in Figure 1, the levels of TLR-4 protein were very low in normal breast tissues. The strength of positive staining gradually increased from ER- premenopausal patients in situ to postmenopausal patients (Figure 1). The expression of TLR-4 was found to be significantly associated with clinical parameters such as ER-pre- or postmenopausal age.

\section{Interaction between TLR-4 polymorphism (rs2770150, rs 1075993I, rs 10759932, and rs4986790) and breast cancer risk in the study populations}

DNA samples obtained from the blood of 127 breast cancer patients and 117 healthy controls were included in this study. Distribution of TLR-4 SNPs genotype and allele frequencies in breast cancer cases and control population are given in Table 2. Four TLR-4 SNPs (rs2770150 T/C, rs10759931 $\mathrm{A} / \mathrm{G}, r s 10759932 \mathrm{~T} / \mathrm{C}$, and $r s 4986790 \mathrm{~A} / \mathrm{G})$ were genotyped and tested for the Hardy-Weinberg equilibrium. The distribution of alleles and genotypes and the association analysis are reported in Table 2. The data for three TLR-4 SNPs, rs2770150, rs 10759932, and rs4986790, located in the promoter, did not present any correlation with breast cancer in the Saudi population (Table 2). However, the frequencies of rs $10759931 \mathrm{SNP}$ (Asp299Gly) in breast cancer cases were significantly different from the healthy controls. The $\mathrm{G}$ allele was found to be significantly higher in frequency among the patients (36\%) compared to the control group (27\%) (Table 2). These data suggested that TLR-4 Asp299Gly SNP is strongly associated with increased susceptibility to breast cancer in the Saudi Arabian population.

\section{Link between pre- and postmenopause status and the genotype frequencies of TLR-4 gene polymorphism in breast cancer patients}

The analysis of the TLR-4 genotype distribution after correlation with age indicated that the median age of onset of 
A

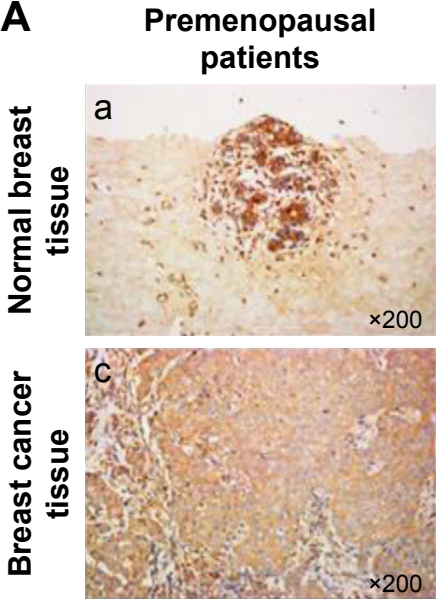

Postmenopausal patients

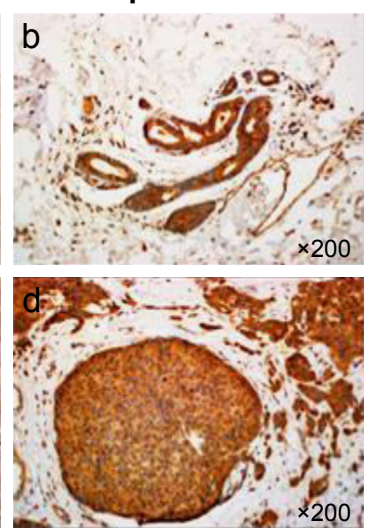

B

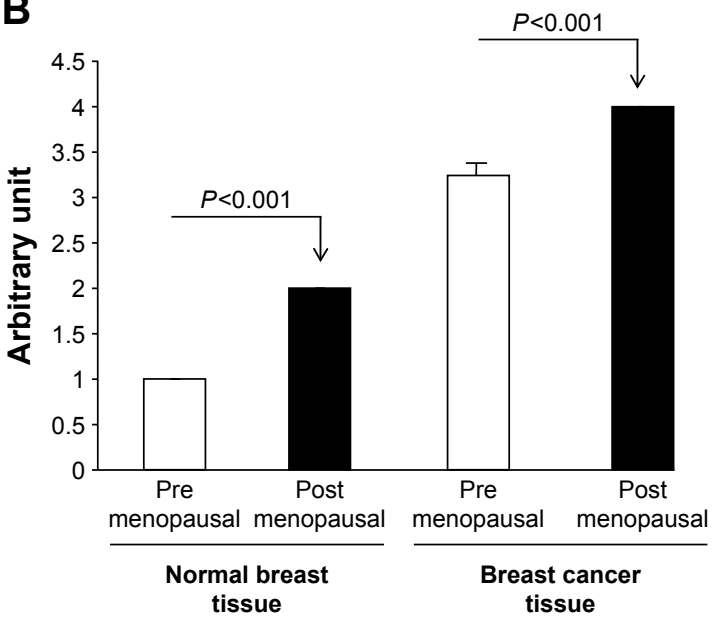

Figure I Immunohistochemical determination of TLR-4 protein expression in normal and breast cancer tissues. (A) Representative sections $(\times 200)$ of positive immunostaining of TLR-4 protein expression in normal breast tissues ( $a$ and b) and ER-breast cancer tissues ( $c$ and d). The staining of samples from ER- premenopausal patients is illustrated in ( $a$ and $c$ ) and from ER- postmenopausal patients in (b and d). Tissues were immunostained using specific TLR-4 antibodies. (B) TLR-4 positive staining was estimated as follows: 0 point, no positive staining; I point, $<20 \%$ positive staining; 2 points, $21 \%-50 \%$ positive staining; 3 points, $51 \%-75 \%$ positive staining; and 4 points, $>75 \%$ positive staining.

Abbreviations: TLR-4, Toll-like receptor 4; ER, estrogen receptor.

breast cancer patients included in the study was 48 years. To investigate the association of TLR-4 SNPs with a younger age at diagnosis of breast cancer, we classified the patients as aged $\leq 48$ or $>48$ years. The genotype distribution for the individual SNP along with the statistical analysis is given in Tables 3 and 4. Interestingly, patients over 48 years of age showed higher numbers of the C allele of SNP rs 2770150 than healthy subjects ( $43 \%$ versus $28 \%$, respectively)

Table 2 Frequencies of TLR-4 gene polymorphism in breast cancer

\begin{tabular}{|c|c|c|c|c|c|c|}
\hline Polymorphism & Patients & Control & OR & $\mathrm{Cl}$ & $\chi^{2}$ & $P$-value \\
\hline \multicolumn{7}{|l|}{ rs 2770150} \\
\hline $\mathrm{T}$ & $154(0.62)$ & $87(0.70)$ & Ref & & & \\
\hline$C$ & $96(0.38)$ & $37(0.30)$ & 1.466 & $0.924-2.325$ & 2.65 & 0.10347 \\
\hline TT & $53(0.42)$ & $32(0.52)$ & Ref & & & \\
\hline TC & $48(0.38)$ & $23(0.37)$ & 1.260 & $0.649-2.445$ & 0.47 & 0.49409 \\
\hline $\mathrm{CC}$ & $24(0.19)$ & $7(0.11)$ & 2.070 & $0.80 I-5.349$ & 2.31 & 0.12850 \\
\hline $\mathrm{TC}+\mathrm{CC}$ & $72(0.58)$ & $30(0.48)$ & 1.449 & $0.786-2.67 \mid$ & 1.42 & 0.23360 \\
\hline \multicolumn{7}{|l|}{ rs I075993| } \\
\hline G & 91 (0.36) & $62(0.27)$ & Ref & & & \\
\hline$A$ & $161(0.64)$ & $170(0.73)$ & 0.645 & $0.438-0.951$ & 4.92 & $0.02650 *$ \\
\hline$A A$ & $13(0.10)$ & $8(0.07)$ & Ref & & & \\
\hline GA & $65(0.52)$ & $46(0.40)$ & 0.870 & $0.334-2.267$ & 0.08 & 0.77488 \\
\hline GG & $48(0.38)$ & $62(0.53)$ & 0.476 & $0.183-1.242$ & 2.37 & 0.12407 \\
\hline $\mathrm{GA}+\mathrm{GG}$ & $113(0.90)$ & $108(0.93)$ & 0.644 & $0.257-1.615$ & 0.89 & 0.34496 \\
\hline \multicolumn{7}{|l|}{ rs 10759932} \\
\hline $\mathrm{T}$ & $39(0.15)$ & $43(0.19)$ & Ref & & & \\
\hline C & $213(0.85)$ & $179(0.8 I)$ & 1.312 & $0.814-2.113$ & 1.25 & 0.26348 \\
\hline $\mathrm{CC}$ & $4(0.03)$ & $6(0.05)$ & Ref & & & \\
\hline TC & $31(0.25)$ & $31(0.28)$ & 1.500 & $0.385-5.842$ & 0.34 & 0.55712 \\
\hline TT & $91(0.72)$ & $74(0.67)$ & 1.845 & $0.502-6.781$ & 0.87 & 0.35034 \\
\hline $\mathrm{TC}+\mathrm{TT}$ & $122(0.97)$ & $105(0.95)$ & 1.743 & $0.479-6.343$ & 0.73 & 0.39396 \\
\hline \multicolumn{7}{|l|}{ rs4986790 } \\
\hline A & $238(0.97)$ & $216(0.94)$ & Ref & & & \\
\hline G & $8(0.03)$ & $14(0.06)$ & 0.519 & $0.213-1.260$ & 2.17 & 0.14099 \\
\hline$A A$ & $115(0.93)$ & $101(0.88)$ & Ref & & & \\
\hline AG & $8(0.07)$ & $14(0.12)$ & 0.502 & $0.202-1.245$ & 2.28 & 0.13127 \\
\hline GG & $0(0.00)$ & $0(0.00)$ & 0.879 & $0.017-44.691$ & - & I \\
\hline$A G+G G$ & $8(0.07)$ & $14(0.12)$ & 0.502 & $0.202-1.245$ & 2.28 & 0.13127 \\
\hline
\end{tabular}

Note: *Statistically significant $(P<0.05)$.

Abbreviations: TLR-4, Toll-like receptor 4; OR, odds ratio; $\mathrm{Cl}$, confidence interval; Ref, reference. 
Table 3 Genotype frequencies of TLR-4 in breast cancer patients aged $<48$ years versus control

\begin{tabular}{|c|c|c|c|c|c|c|}
\hline Polymorphism & Patients & Control & OR & Cl & $\chi^{2}$ & $P$-value \\
\hline \multicolumn{7}{|l|}{ rs 2770150} \\
\hline TT & $22(0.5 \mathrm{I})$ & $32(0.52)$ & Ref & & & \\
\hline TC & $17(0.40)$ & $23(0.37)$ & 1.075 & $0.469-2.464$ & 0.03 & 0.86410 \\
\hline $\mathrm{CC}$ & $4(0.09)$ & $7(0.11)$ & 0.831 & $0.217-3.184$ & 0.07 & 0.78709 \\
\hline $\mathrm{TC}+\mathrm{CC}$ & $21(0.49)$ & $30(0.48)$ & 1.018 & $0.468-2.217$ & 0.00 & 0.96380 \\
\hline $\mathrm{T}$ & $6 I(0.7 I)$ & $87(0.70)$ & Ref & & & \\
\hline C & $25(0.29)$ & $37(0.30)$ & 0.964 & $0.527-1.763$ & 0.01 & 0.90438 \\
\hline \multicolumn{7}{|l|}{ rs|075993| } \\
\hline $\mathrm{AA}$ & $6(0.14)$ & $5(0.08)$ & Ref & & & \\
\hline GA & $21(0.48)$ & $25(0.40)$ & 0.700 & $0.187-2.623$ & 0.28 & 0.59564 \\
\hline GG & $17(0.39)$ & $32(0.52)$ & 0.443 & $0.118-1.665$ & 1.50 & 0.22104 \\
\hline $\mathrm{GA}+\mathrm{GG}$ & $38(0.86)$ & $57(0.92)$ & 0.556 & $0.158-1.950$ & 0.86 & 0.35400 \\
\hline G & $33(0.38)$ & $35(0.28)$ & Ref & & & \\
\hline A & $55(0.63)$ & $89(0.72)$ & 0.655 & $0.366-1.173$ & 2.03 & 0.15402 \\
\hline \multicolumn{7}{|l|}{ rs10759932 } \\
\hline $\mathrm{CC}$ & $0(0.00)$ & $4(0.07)$ & Ref & & & \\
\hline TC & II (0.25) & $13(0.22)$ & 7.667 & $0.372-158$ & 3.02 & 0.08226 \\
\hline TT & $33(0.75)$ & $4 I(0.7 I)$ & 7.265 & $0.378-139.78$ & 3.09 & 0.07868 \\
\hline $\mathrm{TC}+\mathrm{TT}$ & $44(1.00)$ & $54(0.93)$ & 7.349 & $0.38-140.18$ & 3.16 & 0.07554 \\
\hline $\mathrm{T}$ & II (0.13) & $21(0.18)$ & Ref & & & \\
\hline C & $77(0.88)$ & $95(0.82)$ & 1.547 & $0.703-3.406$ & 1.19 & 0.27574 \\
\hline \multicolumn{7}{|l|}{ rs4986790 } \\
\hline AA & $4 I(0.93)$ & $53(0.85)$ & Ref & & & \\
\hline AG & $3(0.07)$ & $9(0.15)$ & 0.431 & $0.110-1.694$ & 1.52 & 0.21775 \\
\hline GG & $0(0.00)$ & $0(0.00)$ & 1.289 & $0.025-66.34$ & - & 1 \\
\hline$A G+G G$ & $3(0.07)$ & $9(0.15)$ & 0.431 & $0.110-1.694$ & 1.52 & 0.21775 \\
\hline A & $85(0.97)$ & II $15(0.93)$ & Ref & & & \\
\hline G & $3(0.03)$ & $9(0.07)$ & 0.451 & $0.119-1.716$ & 1.43 & 0.36680 \\
\hline
\end{tabular}

Abbreviations: TLR-4, Toll-like receptor 4; OR, odds ratio; $\mathrm{Cl}$, confidence interval; Ref, reference.

(OR 1.985; 95\% CI 1.177-3.346 and $P=0.00956$ ). The prevalence of the homozygous CC of the same SNP was also significantly increased in the patient group compared to the control group ( $24 \%$ versus $2 \%$, respectively) (Table 4 ). However, we did not find any association between this SNP and the subpopulation of patients $<48$ years of age (Table 3 ). Additionally, no significant difference in the distribution of genotypes between patients and healthy controls for both subpopulations was observed $(P>0.05)$ for the other three SNPs (rs10759931, rs10759932, and rs4986790; Tables 3 and 4).

\section{Association between the genotype frequencies of TLR-4 gene polymorphism and ER status}

We next wanted to evaluate the association of breast cancer risk with the individual SNPs based on the patient's ER status. The genotype distributions in the ER+ and the ERbreast cancer patient groups were compared with those of the ER+ and ER- control subjects, respectively (Tables 5 and 6). Interestingly, in the ER-group, the AA genotype of
SNP $r s 4986790$ presented a frequency that was significantly higher in the patients than in the controls ( $98 \%$ versus $88 \%$, respectively). Similarly, the genotype AG was significantly less frequent in the cases compared to the controls $(2 \%$ versus $12 \%$, respectively) (OR 0.16 ; $95 \%$ CI $0.020-1.257$ and $P=0.04860$ ) (Table 5). However, this SNP was not associated with breast cancer in the ER+ group (Table 6). For SNPs rs2770150, rs10759931, and rs10759932, no significant difference in the distribution of genotypes between affected and non-affected ER+ and ER- status was observed $(P>0.05)$ (Tables 5 and 6).

\section{Discussion}

TLR-4 activation has been previously shown to promote tumor progression and chemoresistance in breast cancer, ${ }^{40,41}$ whereas impairment of the TLR-4 signaling pathway can reduce breast cancer growth and prolong survival. ${ }^{9}$ Our hypothesis is that TLR-4 plays an important role in activating innate immune system and that dysregulation of this receptor compromises the immune surveillance leading to breast cancer progression and metastasis. Using a Saudi 
Table 4 Genotype frequencies of TLR- 4 in breast cancer patients aged $>48$ years versus control

\begin{tabular}{|c|c|c|c|c|c|c|}
\hline Polymorphism & Patients & Control & OR & $\mathrm{Cl}$ & $x^{2}$ & $P$-value \\
\hline \multicolumn{7}{|l|}{ rs 2770150} \\
\hline TT & $31(0.38)$ & $25(0.46)$ & Ref & & & \\
\hline TC & $31(0.38)$ & $28(0.52)$ & 0.893 & $0.429-1.860$ & 0.09 & 0.76214 \\
\hline $\mathrm{CC}$ & $20(0.24)$ & I $(0.02)^{\prime}$ & 16.129 & $2.022-128.63$ & 10.86 & $0.00098 *$ \\
\hline $\mathrm{TC}+\mathrm{CC}$ & $51(0.62)$ & $29(0.54)$ & 1.418 & $0.707-2.847$ & 0.97 & 0.32487 \\
\hline $\mathrm{T}$ & $93(0.57)$ & $78(0.72)$ & Ref & & & \\
\hline C & $71(0.43)$ & $30(0.28)$ & 1.985 & $1.177-3.346$ & 6.71 & $0.00956 *$ \\
\hline \multicolumn{7}{|l|}{ rs |075993| } \\
\hline $\mathrm{AA}$ & $7(0.09)$ & $3(0.06)$ & Ref & & & \\
\hline GA & $44(0.54)$ & $21(0.39)$ & 0.898 & $0.211-3.824$ & 0.02 & $0.8842 I$ \\
\hline GG & $31(0.38)$ & $30(0.56)$ & 0.443 & $0.105-1.874$ & 1.27 & 0.25966 \\
\hline $\mathrm{GA}+\mathrm{GG}$ & 75 (0.91) & $51(0.94)$ & 0.630 & $0.156-2.552$ & 0.42 & 0.51459 \\
\hline G & $58(0.35)$ & $27(0.25)$ & Ref & & & \\
\hline A & $106(0.65)$ & $81(0.75)$ & 0.609 & $0.355-1.046$ & 3.26 & 0.07113 \\
\hline \multicolumn{7}{|l|}{ rs10759932 } \\
\hline CC & $4(0.05)$ & $2(0.04)$ & Ref & & & \\
\hline TC & $20(0.24)$ & $18(0.34)$ & 0.556 & $0.09 \mid-3.405$ & $0.4 I$ & 0.52111 \\
\hline TT & $58(0.7 I)$ & $33(0.62)$ & 0.879 & $0.153-5.059$ & 0.02 & 0.88489 \\
\hline $\mathrm{TC}+\mathrm{TT}$ & $78(0.95)$ & $51(0.96)$ & 0.765 & $0.135-4.329$ & 0.09 & 0.76106 \\
\hline $\mathrm{T}$ & $28(0.17)$ & $22(0.21)$ & Ref & & & \\
\hline C & $136(0.83)$ & $84(0.79)$ & $\mathrm{I} .272$ & $0.684-2.367$ & 0.58 & 0.44696 \\
\hline \multicolumn{7}{|l|}{ rs4986790 } \\
\hline AA & $74(0.94)$ & $48(0.91)$ & Ref & & & \\
\hline AG & $5(0.06)$ & $5(0.09)$ & 0.649 & $0.178-2.360$ & 0.44 & $0.5087 \mid$ \\
\hline GG & $0(0.00)$ & $0(0.00)$ & $0.65 I$ & $0.013-33.359$ & - & I \\
\hline$A G+G G$ & $5(0.06)$ & $5(0.09)$ & 0.649 & $0.178-2.360$ & 0.44 & $0.5087 \mid$ \\
\hline \multirow[t]{2}{*}{ A } & $153(0.97)$ & 101 & Ref & & & \\
\hline & & $(0.95)$ & & & & \\
\hline G & $5(0.03)$ & $5(0.05)$ & 0.660 & $0.186-2.338$ & 0.42 & $0.5287 \mid$ \\
\hline
\end{tabular}

Note: *Statistically significant $(P<0.05)$.

Abbreviations: TLR-4, Toll-like receptor 4; OR, odds ratio; $\mathrm{Cl}$, confidence interval; Ref, reference.

Table 5 Genotype frequencies of TLR-4 in ER- breast cancer patients versus control

\begin{tabular}{|c|c|c|c|c|c|c|}
\hline Polymorphism & Patients & Control & OR & $\mathrm{Cl}$ & $\chi^{2}$ & $P$-value \\
\hline \multicolumn{7}{|l|}{ rs 2770150} \\
\hline TT & $23(0.47)$ & $32(0.52)$ & Ref & & & \\
\hline TC & $18(0.37)$ & $23(0.37)$ & 1.089 & $0.48 I-2.465$ & 0.04 & 0.83819 \\
\hline $\mathrm{CC}$ & $8(0.16)$ & $7(0.11)$ & 1.590 & $0.505-5.008$ & 0.63 & 0.42612 \\
\hline $\mathrm{TC}+\mathrm{CC}$ & $26(0.53)$ & $30(0.48)$ & 1.206 & $0.569-2.553$ & 0.24 & 0.62478 \\
\hline $\mathrm{T}$ & $64(0.65)$ & $87(0.70)$ & Ref & & & \\
\hline C & $34(0.35)$ & $37(0.30)$ & 1.249 & $0.709-2.201$ & 0.59 & $0.44 I 20$ \\
\hline \multicolumn{7}{|l|}{ rs I075993 | } \\
\hline AA & $5(0.10)$ & $8(0.07)$ & Ref & & & \\
\hline GA & $26(0.53)$ & $46(0.40)$ & 0.904 & $0.268-3.052$ & 0.03 & $0.87 \mid 28$ \\
\hline GG & $18(0.37)$ & $62(0.53)$ & 0.465 & $0.135-1.596$ & 1.53 & 0.21603 \\
\hline $\mathrm{GA}+\mathrm{GG}$ & $44(0.90)$ & $108(0.93)$ & 0.652 & $0.202-2.102$ & 0.52 & 0.47117 \\
\hline G & $36(0.37)$ & $62(0.27)$ & Ref & & & \\
\hline A & $62(0.63)$ & $170(0.73)$ & 0.628 & $0.380-1.039$ & 3.31 & 0.06899 \\
\hline \multicolumn{7}{|l|}{ rs 10759932} \\
\hline CC & I (0.02) & $6(0.05)$ & Ref & & & \\
\hline TC & $12(0.24)$ & $31(0.28)$ & 2.323 & $0.252-21.372$ & 0.58 & 0.44610 \\
\hline $\mathrm{TT}$ & $36(0.73)$ & $74(0.67)$ & 2.919 & $0.339-25.162$ & 1.04 & 0.30897 \\
\hline $\mathrm{TC}+\mathrm{TT}$ & $48(0.98)$ & $105(0.95)$ & 2.743 & $0.32 I-23.4 I 5$ & 0.92 & 0.33752 \\
\hline $\mathrm{T}$ & $14(0.14)$ & $43(0.19)$ & Ref & & & \\
\hline C & $84(0.86)$ & $179(0.81)$ & $|.44|$ & $0.748-2.779$ & 1.20 & 0.27328 \\
\hline \multicolumn{7}{|l|}{ rs4986790 } \\
\hline AA & $45(0.98)$ & I0I (0.88) & Ref & & & \\
\hline AG & I (0.02) & $14(0.12)$ & 0.160 & $0.020-1.257$ & 3.89 & $0.04860 *$ \\
\hline GG & $0(0.00)$ & $0(0.00)$ & 2.231 & $0.044-114.18$ & - & I \\
\hline$A G+G G$ & I (0.02) & $14(0.12)$ & 0.160 & $0.020-1.257$ & 3.89 & $0.04860 *$ \\
\hline A & $91(0.99)$ & $216(0.94)$ & Ref & & & \\
\hline G & $\mathrm{I}(0.0 \mathrm{I})$ & $14(0.06)$ & 0.170 & $0.022-1.308$ & 3.70 & 0.07686 \\
\hline
\end{tabular}

Note: * Statistically significant $(P<0.05)$.

Abbreviations: TLR-4, Toll-like receptor 4; ER, estrogen receptor; OR, odds ratio; Cl, confidence interval; Ref, reference. 
Table 6 Genotype frequencies of TLR-4 in ER+ breast cancer patients versus control

\begin{tabular}{|c|c|c|c|c|c|c|}
\hline Polymorphism & Patients & Control & OR & Cl & $x^{2}$ & $P$-value \\
\hline \multicolumn{7}{|l|}{ rs 2770150} \\
\hline TT & $30(0.4 I)$ & $32(0.52)$ & Ref & & & \\
\hline TC & $29(0.39)$ & $23(0.37)$ & 1.345 & $0.642-2.819$ & 0.62 & 0.43208 \\
\hline $\mathrm{CC}$ & $15(0.20)$ & $7(0.11)$ & 2.286 & $0.819-6.378$ & 2.56 & 0.10973 \\
\hline $\mathrm{TC}+\mathrm{CC}$ & $44(0.59)$ & $30(0.48)$ & 1.564 & $0.792-3.090$ & 1.67 & 0.19662 \\
\hline $\mathrm{T}$ & $89(0.60)$ & $87(0.70)$ & Ref & & & \\
\hline C & $59(0.40)$ & $37(0.30)$ & 1.559 & $0.940-2.586$ & 2.97 & 0.08483 \\
\hline \multicolumn{7}{|l|}{ rs|0759931 } \\
\hline AA & $8(0.11)$ & $8(0.07)$ & Ref & & & \\
\hline GA & $38(0.5 \mathrm{I})$ & $46(0.40)$ & 0.826 & $0.283-2.408$ & 0.12 & $0.726 \mid 4$ \\
\hline GG & $29(0.39)$ & $62(0.53)$ & 0.468 & $0.160-1.370$ & 1.98 & 0.15965 \\
\hline $\mathrm{GA}+\mathrm{GG}$ & $67(0.89)$ & $108(0.93)$ & 0.620 & $0.222-|.73|$ & 0.84 & 0.35839 \\
\hline G & $54(0.36)$ & $62(0.27)$ & Ref & & & \\
\hline A & $96(0.64)$ & $170(0.73)$ & 0.648 & $0.417-1.009$ & 3.71 & 0.05419 \\
\hline \multicolumn{7}{|l|}{ rs10759932 } \\
\hline $\mathrm{CC}$ & $3(0.04)$ & $6(0.05)$ & Ref & & & \\
\hline TC & $18(0.24)$ & $31(0.28)$ & 1.161 & $0.258-5.219$ & 0.04 & 0.84527 \\
\hline TT & $54(0.72)$ & $74(0.67)$ & 1.459 & $0.349-6.096$ & 0.27 & 0.60244 \\
\hline $\mathrm{TC}+\mathrm{TT}$ & $72(0.96)$ & $105(0.95)$ & $1.37 \mid$ & $0.332-5.662$ & 0.19 & 0.66126 \\
\hline $\mathrm{T}$ & $24(0.16)$ & $43(0.19)$ & Ref & & & \\
\hline C & $126(0.84)$ & $179(0.8 \mathrm{I})$ & 1.261 & $0.728-2.184$ & 0.69 & 0.40678 \\
\hline \multicolumn{7}{|l|}{ rs4986790 } \\
\hline AA & $68(0.91)$ & $101(0.88)$ & Ref & & & \\
\hline AG & $7(0.09)$ & $14(0.12)$ & 0.743 & $0.285-1.936$ & 0.37 & 0.54160 \\
\hline GG & $0(0.00)$ & $0(0.00)$ & 1.482 & $0.029-75.574$ & - & I \\
\hline$A G+G G$ & $7(0.09)$ & $14(0.12)$ & 0.743 & $0.285-1.936$ & 0.37 & 0.54160 \\
\hline A & I43 (0.95) & $216(0.94)$ & Ref & & & \\
\hline G & $7(0.05)$ & $14(0.06)$ & 0.755 & $0.298-1.917$ & 0.35 & 0.55367 \\
\hline
\end{tabular}

Abbreviations: TLR-4, Toll-like receptor 4; ER, estrogen receptor; OR, odds ratio; Cl, confidence interval; Ref, reference.

population, we demonstrated that TLR-4 is overexpressed in ER-, postmenopausal breast cancer patients compared to normal controls. Thus, an increase in TLR- 4 could be seen as a biological indicator of potential cancer in ER-, postmenopausal patients. Interestingly, the presence of a higher level of TLR-4 protein in breast cancer tissue supports previous studies reporting an overexpression of TLR-4 in various types of cancers, including gastric cancer, ${ }^{42}$ breast cancer, ${ }^{40,41,43}$ colon cancer, ${ }^{38,43}$ and ovarian cancer. ${ }^{44}$ Higher TLR-4 expression was also shown to be significantly associated with invasive ductal carcinoma, one of the most common types of breast cancer. ${ }^{45}$ Evidence has demonstrated that TLR-4 activation promotes tumor cell adhesion and metastasis. ${ }^{46,47}$ Injection of 4T1 tumor cells into TLR-4-/- mice leads to increased tumor volume and lung metastasis. ${ }^{9}$ In agreement with these studies, we suggest that high activation of TLR-4 in breast cancerous tissues may promote tumor growth and resistance to apoptosis.

Genetic alterations in the TLR pathway are also known to be associated with an increased risk of developing breast cancer. ${ }^{48}$ This is the first study investigating the role of several common TLR-4 polymorphisms in susceptibility to breast cancer in Saudi Arabia. We identified that the TLR-4 polymorphism rs 10759931 could be a risk factor for this disease in the Saudi Arabian population. This polymorphism affects the population regardless of ER status or age group. In contrast, the TLR-4 polymorphism rs2770150 is correlated with breast cancer in patients 48 years and older, which is in agreement with the decreased levels of female sex hormones during the postmenopausal period. However, Marino $^{49}$ has linked the crucial role of estrogen and progesterone in protecting against colon cancer particularly in women patients. ${ }^{49-52}$ Our previous study showed that TLR-4 rs2770150 is associated with colon cancer in postmenopausal Saudi women..$^{38}$ The TLR-4 polymorphism rs4986790 is associated with this malignancy in the ER-patient groups. These two SNPs were shown to be strongly associated with prostate cancer ${ }^{53}$ and gastric cancer ${ }^{54}$ in other studies and in other populations. TLR-4 rs4986790 is the most common polymorphism, which causes an amino acid exchange (aspartate to glycine) at position 299 (Asp200Gly) located within the extracellular domain of the receptor. This polymorphism causes a significant local conformational change at the D299G site, ${ }^{55}$ which may abolish ligand binding, 
and consequently, impair the TLR-4 signaling response to LPS. ${ }^{56}$ This polymorphism was also shown to be associated with an increased risk of breast cancer. ${ }^{33}$ Recently, we have demonstrated that these same TLR-4 SNPs were associated with TLR-4 expression and colon cancer susceptibility in Saudi patients. ${ }^{38}$ Because TLR-4 plays an active role in the innate immune system, the loss of function of this protein may lead to a depressed immune response, thus promoting cancer development.

In conclusion, our study shows for the first time that TLR-4 polymorphism rs 10759931 is strongly associated with risk of breast cancer in the Saudi population. Our data suggest that genetic variation in TLR-4 may influence the development of this disease. We believe that our study provides support for a better understanding of the implication of TLR-4 polymorphism in breast tumorigenesis and for its eventual use as a cancer biomarker.

\section{Abbreviations}

$\mathrm{CI}$, confidence interval; ER, estrogen receptor; IHC, immunohistochemistry; IL, interleukin; KFMC, King Faisal Medical City; KSA, Kingdom of Saudi Arabia; LPS, lipopolysaccharide; OR, odds ratio; SNP, single-nucleotide polymorphism; TLR, Toll-like receptor.

\section{Acknowledgment}

This project was supported by the Research Group Program (number RGP-VPP-260) in the KSA.

\section{Disclosure}

The authors report no conflicts of interest in this work.

\section{References}

1. American Cancer Society. Cancer Facts \& Figures 2013. Available from: https://www.cancer.org/research/cancer-facts-statistics/all-cancer-factsfigures/cancer-facts-figures-2013.html. Accessed February 8, 2017.

2. Yu H, Kortylewski M, Pardoll D. Crosstalk between cancer and immune cells: role of STAT3 in the tumour microenvironment. Nat Rev Immunol. 2007;7(1):41-51.

3. Mavaddat N, Antoniou AC, Easton DF, Garcia-Closas M. Genetic susceptibility to breast cancer. Mol Oncol. 2010;4(3):174-191.

4. Yu JC, Ding SL, Chang CH, et al. Genetic susceptibility to the development and progression of breast cancer associated with polymorphism of cell cycle and ubiquitin ligase genes. Carcinogenesis. 2009;30(9): $1562-1570$

5. de Visser KE, Eichten A, Coussens LM. Paradoxical roles of the immune system during cancer development. Nat Rev Cancer. 2006;6(1): 24-37.

6. Yang CX, Li CY, Feng W. Toll-like receptor 4 genetic variants and prognosis of breast cancer. Tissue Antigens. 2013;81(4):221-226.

7. Ma FJ, Liu ZB, Hu X, et al. Prognostic value of myeloid differentiation primary response 88 and Toll-like receptor 4 in breast cancer patients. PLoS One. 2014;9(10):e111639.
8. Yang H, Wang B, Wang T, et al. Toll-like receptor 4 prompts human breast cancer cells invasiveness via lipopolysaccharide stimulation and is overexpressed in patients with lymph node metastasis. PLoS One. 2014;9(10):e109980.

9. Ahmed A, Wang JH, Redmond HP. Silencing of TLR4 increases tumor progression and lung metastasis in a murine model of breast cancer. Ann Surg Oncol. 2013;20(Suppl 3):S389-S396.

10. Bergmann C, Bachmann HS, Bankfalvi A, et al. Toll-like receptor 4 single-nucleotide polymorphisms Asp299Gly and Thr399lle in head and neck squamous cell carcinomas. J Transl Med. 2011;9:139.

11. Bhatelia K, Singh K, Singh R. TLRs: linking inflammation and breast cancer. Cell Signal. 2014;26(11):2350-2357.

12. Rodríguez NC, Kaakoush N, Khean-Lee G, Ming FK, Mitchell H. Pattern recognition receptors in helicobacter pylori-related gastric cancer. Helicobacter. 2014;19:85.

13. Basith S, Manavalan B, Yoo TH, Kim SG, Choi S. Roles of toll-like receptors in cancer: a double-edged sword for defense and offense. Arch Pharm Res. 2012;35(8):1297-1316.

14. Drexler SK, Foxwell BM. The role of Toll-like receptors in chronic inflammation. Int J Biochem Cell Biol. 2010;42(4):506-518.

15. Schreibelt G, Tel J, Sliepen KH, et al. Toll-like receptor expression and function in human dendritic cell subsets: implications for dendritic cell-based anti-cancer immunotherapy. Cancer Immunol Immunother. 2010;59(10):1573-1582.

16. Kurt-Jones EA, Popova L, Kwinn L, et al. Pattern recognition receptors TLR4 and CD14 mediate response to respiratory syncytial virus. Nat Immunol. 2000;1(5):398-401.

17. Rassa JC, Meyers JL, Zhang Y, Kudaravalli R, Ross SR. Murine retroviruses activate B cells via interaction with toll-like receptor 4. Proc Natl Acad Sci U S A. 2002;99(4):2281-2286.

18. Huang B, Zhao J, Li H, et al. Toll-like receptors on tumor cells facilitate evasion of immune surveillance. Cancer Res. 2005;65(12):5009-5014.

19. Molteni M, Marabella D, Orlandi C, Rossetti C. Melanoma cell lines are responsive in vitro to lipopolysaccharide and express TLR-4. Cancer Lett. 2006;235(1):75-83.

20. Ren T, Wen ZK, Liu ZM, Liang YJ, Guo ZL, Xu L. Functional expression of TLR9 is associated to the metastatic potential of human lung cancer cell: functional active role of TLR9 on tumor metastasis. Cancer Biol Ther. 2007;6(11):1704-1709.

21. Szczepanski MJ, Czystowska M, Szajnik M, et al. Triggering of Tolllike receptor 4 expressed on human head and neck squamous cell carcinoma promotes tumor development and protects the tumor from immune attack. Cancer Res. 2009;69(7):3105-3113.

22. de Oliveira JG, Silva AE. Polymorphisms of the TLR2 and TLR4 genes are associated with risk of gastric cancer in a Brazilian population. World $J$ Gastroenterol. 2012;18(11):1235-1242.

23. Milne AN, Carneiro F, O'Morain C, Offerhaus GJ. Nature meets nurture: molecular genetics of gastric cancer. Hum Genet. 2009;126(5): $615-628$.

24. Garza-Gonzalez E, Bosques-Padilla FJ, Mendoza-Ibarra SI, FloresGutierrez JP, Maldonado-Garza HJ, Perez-Perez GI. Assessment of the toll-like receptor 4 Asp299Gly, Thr399Ile and interleukin-8-25 I polymorphisms in the risk for the development of distal gastric cancer. BMC Cancer. 2007; 7:70.

25. Tahara T, Arisawa T, Wang F, et al. Toll-like receptor 2-196 to 174del polymorphism influences the susceptibility of Japanese people to gastric cancer. Cancer Sci. 2007;98(11):1790-1794.

26. Slattery ML, Herrick JS, Bondurant KL, Wolff RK. Toll-like receptor genes and their association with colon and rectal cancer development and prognosis. Int J Cancer. 2012;130(12):2974-2980.

27. Agúndez JA, García-Martín E, Devesa MJ, et al. Polymorphism of the TLR4 gene reduces the risk of hepatitis $\mathrm{C}$ virus-induced hepatocellular carcinoma. Oncology. 2012;82(1):35-40.

28. Stevens VL, Hsing AW, Talbot JT, et al. Genetic variation in the tolllike receptor gene cluster (TLR10-TLR1-TLR6) and prostate cancer risk. Int J Cancer. 2008;123(11):2644-2650. 
29. Mandal RK, George GP, Mittal RD. Association of Toll-like receptor (TLR) 2, 3 and 9 genes polymorphism with prostate cancer risk in North Indian population. Mol Biol Rep. 2012;39(7):7263-7269.

30. Kim MK, Park SW, Kim SK, et al. Association of Toll-like receptor 2 polymorphisms with papillary thyroid cancer and clinicopathologic features in a Korean population. J Korean Med Sci. 2012;27(11):1333-1338.

31. Priyadarshini A, Chakraborti A, Mandal AK, Singh SK. Asp299Gly and Thr399Ile polymorphism of TLR-4 gene in patients with prostate cancer from North India. Indian J Urol. 2013;29(1):37-41.

32. Niedzielska I, Niedzielski Z, Tkacz M, et al. Toll-like receptors and the tendency of normal mucous membrane to transform to polyp or colorectal cancer. J Physiol Pharmacol. 2009;60(Suppl 1):65-71.

33. Ahmed A, Redmond HP, Wang JH. Links between Toll-like receptor 4 and breast cancer. Oncoimmunology. 2013;2(2):e22945.

34. Apetoh L, Tesniere A, Ghiringhelli F, Kroemer G, Zitvogel L. Molecular interactions between dying tumor cells and the innate immune system determine the efficacy of conventional anticancer therapies. Cancer Res. 2008;68(11):4026-4030.

35. El-Omar EM, Ng MT, Hold GL. Polymorphisms in Toll-like receptor genes and risk of cancer. Oncogene. 2008;27(2):244-252.

36. Barnholtz-Sloan JS, Shetty PB, Guan X, et al. FGFR2 and other loci identified in genome-wide association studies are associated with breast cancer in African-American and younger women. Carcinogenesis. 2010;31(8):1417-1423.

37. Parker RL, Huntsman DG, Lesack DW, et al. Assessment of interlaboratory variation in the immunohistochemical determination of estrogen receptor status using a breast cancer tissue microarray. Am J Clin Pathol. 2002;117(5):723-728.

38. Semlali A, Reddy Parine N, Arafah M, et al. Expression and polymorphism of Toll-like receptor 4 and effect on NF- $\kappa$ B mediated inflammation in colon cancer patients. PLoS One. 2016;11(1):e0146333.

39. Alanazi M, Pathan AA, Abduljaleel Z, et al. Association between PARP-1 V762A polymorphism and breast cancer susceptibility in Saudi population. PLoS One. 2013;8(12):e85541.

40. Yang H, Zhou H, Feng P, et al. Reduced expression of Toll-like receptor 4 inhibits human breast cancer cells proliferation and inflammatory cytokines secretion. J Exp Clin Cancer Res. 2010;29:92.

41. Rajput S, Volk-Draper LD, Ran S. TLR4 is a novel determinant of the response to paclitaxel in breast cancer. Mol Cancer Ther. 2013; 12(8):1676-1687.

42. Yuan X, Zhou Y, Wang W, et al. Activation of TLR4 signaling promotes gastric cancer progression by inducing mitochondrial ROS production. Cell Death Dis. 2013;4:e794.
43. Tang X, Zhu Y. TLR4 signaling promotes immune escape of human colon cancer cells by inducing immunosuppressive cytokines and apoptosis resistance. Oncol Res. 2012;20(1):15-24.

44. Kelly MG, Alvero AB, Chen R, et al. TLR-4 signaling promotes tumor growth and paclitaxel chemoresistance in ovarian cancer. Cancer Res. 2006;66(7):3859-3868.

45. Ehsan N, Murad S, Ashiq T, et al. Significant correlation of TLR4 expression with the clinicopathological features of invasive ductal carcinoma of the breast. Tumour Biol. 2013;34(2):1053-1059.

46. Wang JH, Manning BJ, Wu QD, Blankson S, Bouchier-Hayes D, Redmond HP. Endotoxin/lipopolysaccharide activates NF-kappa B and enhances tumor cell adhesion and invasion through a beta 1 integrindependent mechanism. J Immunol. 2003;170(2):795-804.

47. Liao SJ, Zhou YH, Yuan Y, et al. Triggering of Toll-like receptor 4 on metastatic breast cancer cells promotes $\alpha v \beta 3$-mediated adhesion and invasive migration. Breast Cancer Res Treat. 2012;133(3):853-863.

48. Resler AJ, Malone KE, Johnson LG, et al. Genetic variation in TLR or NFkappaB pathways and the risk of breast cancer: a case-control study. BMC Cancer. 2013;13:219.

49. Marino M. Xenoestrogens challenge 17 $\beta$-estradiol protective effects in colon cancer. World J Gastrointest Oncol. 2014;6(3):67-73.

50. Barzi A, Lenz AM, Labonte MJ, Lenz HJ. Molecular pathways: estrogen pathway in colorectal cancer. Clin Cancer Res. 2013;19(21): 5842-5848.

51. al-Azzawi F, Wahab M. Estrogen and colon cancer: current issues Climacteric. 2002;5(1):3-14.

52. Hendrickse CW, Jones CE, Donovan IA, Neoptolemos JP, Baker PR. Oestrogen and progesterone receptors in colorectal cancer and human colonic cancer cell lines. Br J Surg. 1993;80(5):636-640.

53. Chen YC, Giovannucci E, Lazarus R, Kraft P, Ketkar S, Hunter DJ. Sequence variants of Toll-like receptor 4 and susceptibility to prostate cancer. Cancer Res. 2005;65(24):11771-11778.

54. Santini D, Angeletti S, Ruzzo A, et al. Toll-like receptor 4 Asp299Gly and Thr399Ile polymorphisms in gastric cancer of intestinal and diffuse histotypes. Clin Exp Immunol. 2008;154(3):360-364.

55. Ohto U, Yamakawa N, Akashi-Takamura S, Miyake K, Shimizu T. Structural analyses of human Toll-like receptor 4 polymorphisms D299G and T399I. J Biol Chem. 2012;287(48):40611-40617.

56. Figueroa L, Xiong Y, Song C, Piao W, Vogel SN, Medvedev A. The Asp299Gly polymorphism alters TLR4 signaling by interfering with recruitment of adapter proteins MyD88 and TRIF. J Immunol. 2012;188(9):4506-4515. 


\section{Supplementary material}

Table SI Characteristics of selected TLR-4 polymorphisms

\begin{tabular}{llll}
\hline SNP & Chr/position & Nucleotide change & Region \\
\hline rs2770I50 & Chr 9/II770086I & $-36 / 2 T>C$ & $5^{\prime}$ upstream \\
rs1075993I & Chr 9/II770I869 & $-2604 G>A$ & Promoter \\
rs10759932 & Chr 9/I20465I44 & $-1607 T>C$ & Promoter \\
rs4986790 & Chr 9/II77I3024 & $8552 A>$ G & Exon \\
Asp299Gly & & & \\
\hline
\end{tabular}

Abbreviations: TLR-4, Toll-like receptor 4; SNP, single-nucleotide polymorphism; Chr, chromosome.

\section{Publish your work in this journal}

OncoTargets and Therapy is an international, peer-reviewed, open access journal focusing on the pathological basis of all cancers, potential targets for therapy and treatment protocols employed to improve the management of cancer patients. The journal also focuses on the impact of management programs and new therapeutic agents and protocols on

patient perspectives such as quality of life, adherence and satisfaction. The manuscript management system is completely online and includes a very quick and fair peer-review system, which is all easy to use. Visit http://www.dovepress.com/testimonials.php to read real quotes from published authors. 